\title{
Kinematics of Post-obduction Deformation of the Tertiary Ridge at Al-Khod Village (Muscat, Oman)
}

\author{
Andreas Scharf*, Frank Mattern and Sawsan S. Al-Sadi
}

\begin{abstract}
Department of Earth Sciences, College of Science, Sultan Qaboos University, P.O. Box: 36, PC 123, Al-Khod, Muscat, Sultanate of Oman. *Email: scharfa@squ.edu.om
\end{abstract}

\begin{abstract}
Structural investigations in post-obductional Paleocene to Eocene limestones of the Tertiary Ridge reveal a $\sim 1 \mathrm{~km}$ long WNW-ESE striking strike-slip fault system within the ridge, consisting of two main sub-parallel, strike-slip faults. Considering the geometry of the Harding Strain Ellipse, the orientation of structures between the two strike-slip faults (e.g., Riedel shears, folds, reverse faults) point to left-lateral motion. The abundance of large-scale folds (up to $100 \mathrm{~m}$ in wave length and amplitude) between the two strike-slip faults led us to the interpretation of transpressive conditions in a first approximation. Moreover, the Tertiary Ridge of the study area consists of three distinct structural domains. The faults of Domain A and $\mathrm{C}$ are oriented WNW-ESE, but the trend of the faults in the central Domain B differs by $\sim 10^{\circ}$. The left-lateral strike-slip fault system exists only in Domain B. We propose that the direction of greatest stress during Miocene plate convergence (sigma 1 ) was oriented $032^{\circ} / 212^{\circ}$. Considering the trend of the strike-slip zone and the orientation of sigma 1 , the left-lateral motion must have been transpressive. Sigma 1 is perpendicularly oriented to the domains A and C.

Prior to the Miocene D2 compressional event the study area was affected by a D1 extensional event, related to the opening of the Red Sea and the Gulf of Aden or to gravity-driven normal faulting. The D2 compressional/transpressional structures of the Miocene are reactivating the D1 structures of the Oligocene.
\end{abstract}

Keywords: Tertiary Ridge; Oman; Collision; Strike-slip faulting; Transpression; Sigma 1.

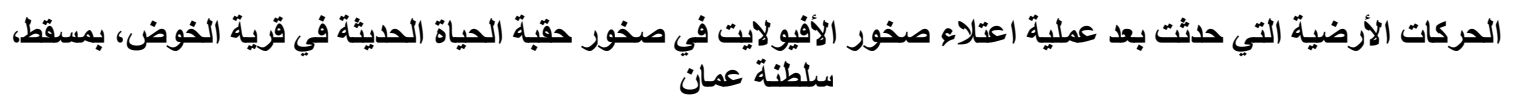

$$
\text { أندرياس شارف, فرانك ماتر, سوسن السعدي }
$$

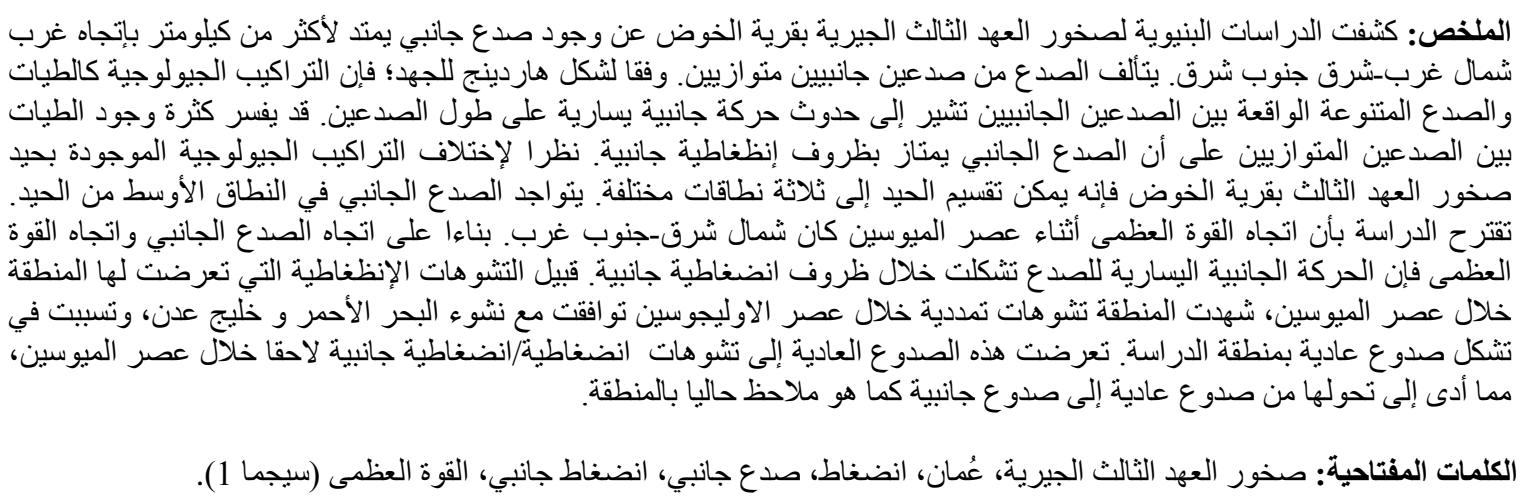

\section{Introduction}

T The Tertiary Ridge is a geomorphological ridge that extends over a distance of $30 \mathrm{~km}$ from Al-Khod Village (west of Muscat) to the east (Figures $1 \& 2$ ). Our studies concern the western part of the ridge, where it is narrow, easy to access and favourably exposed. The ridge consists of three Paleocene to Eocene formations that dip to the NNE. Whereas the oldest and youngest formations (Jafnayn and Seeb fms.) are represented by competent limestone beds, the intervening Rusayl Fm. consists of various lithologies, 
including large quantities of marl, making this formation significantly less competent than the underlying and overlying formations (e.g., [1-3]).

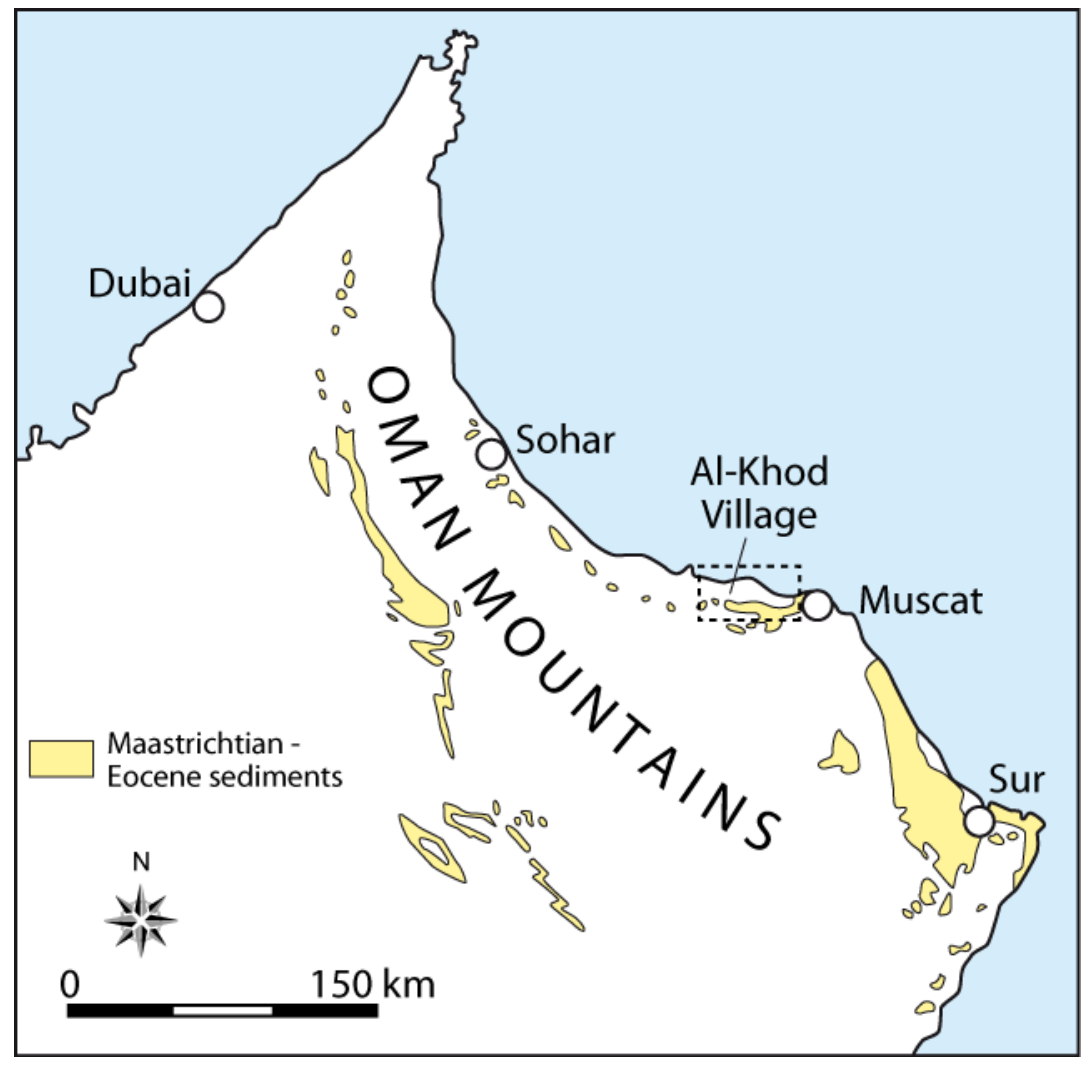

Figure 1. Outcrops of Maastrichtian to Eocene post-obductional sediments of northern Oman. Modified from [1]. Dotted box shows the outline of Figure 2.

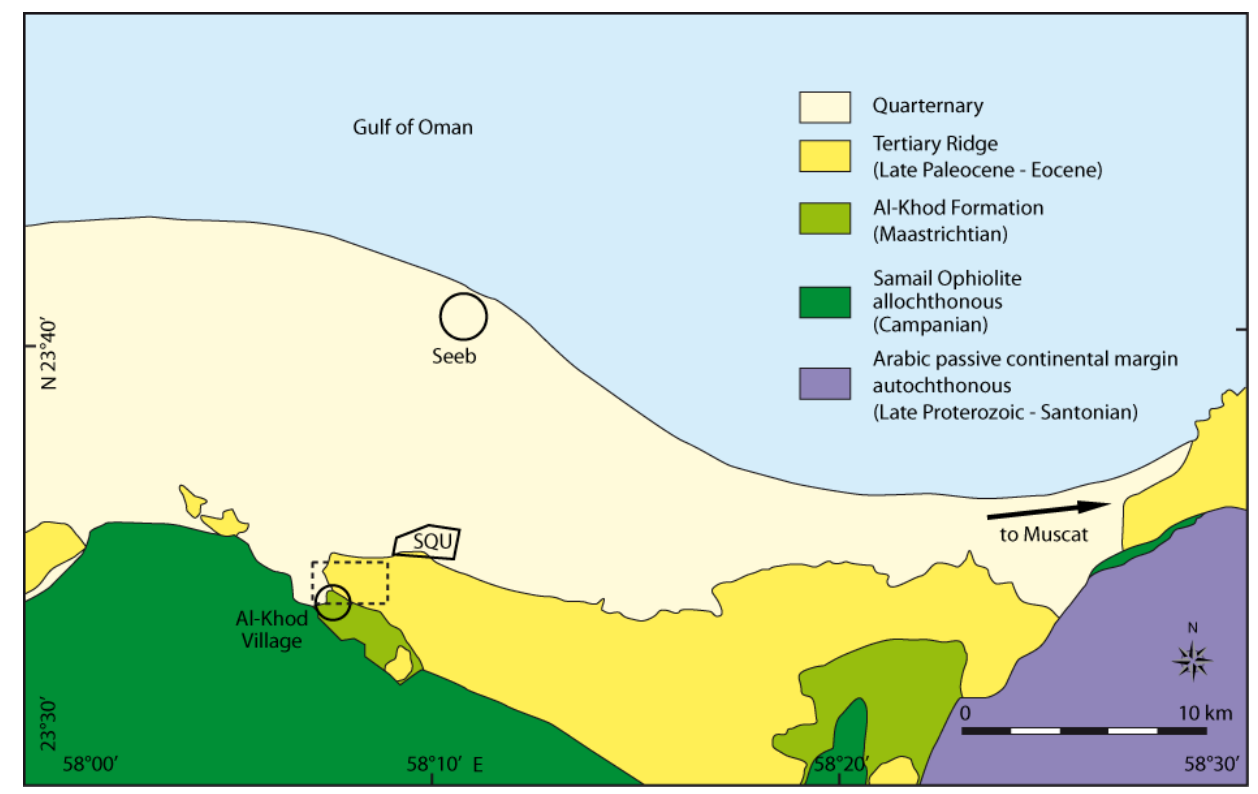

Figure 2. Simplified geological map of the greater study area. The study area is shown in the dotted box (Figure 5). SQU - Sultan Qaboos University campus. Simplified from [4].

Whereas the sedimentary rocks of the Tertiary Ridge are well described and understood (e.g., [1-3]), its deformation has remained a largely untackled issue, despite the high visibility of the superbly and invitingly well-exposed folds within the Rusayl and Jafnayn fms. as in the road outcrop, which cuts across the ridge along the road leading from the north into the village of Al-Khod (Figure 3a, b), or as in natural outcrops $\sim 1$ $\mathrm{km}$ farther ESE in the western part of the ridge (Figure 3c). 

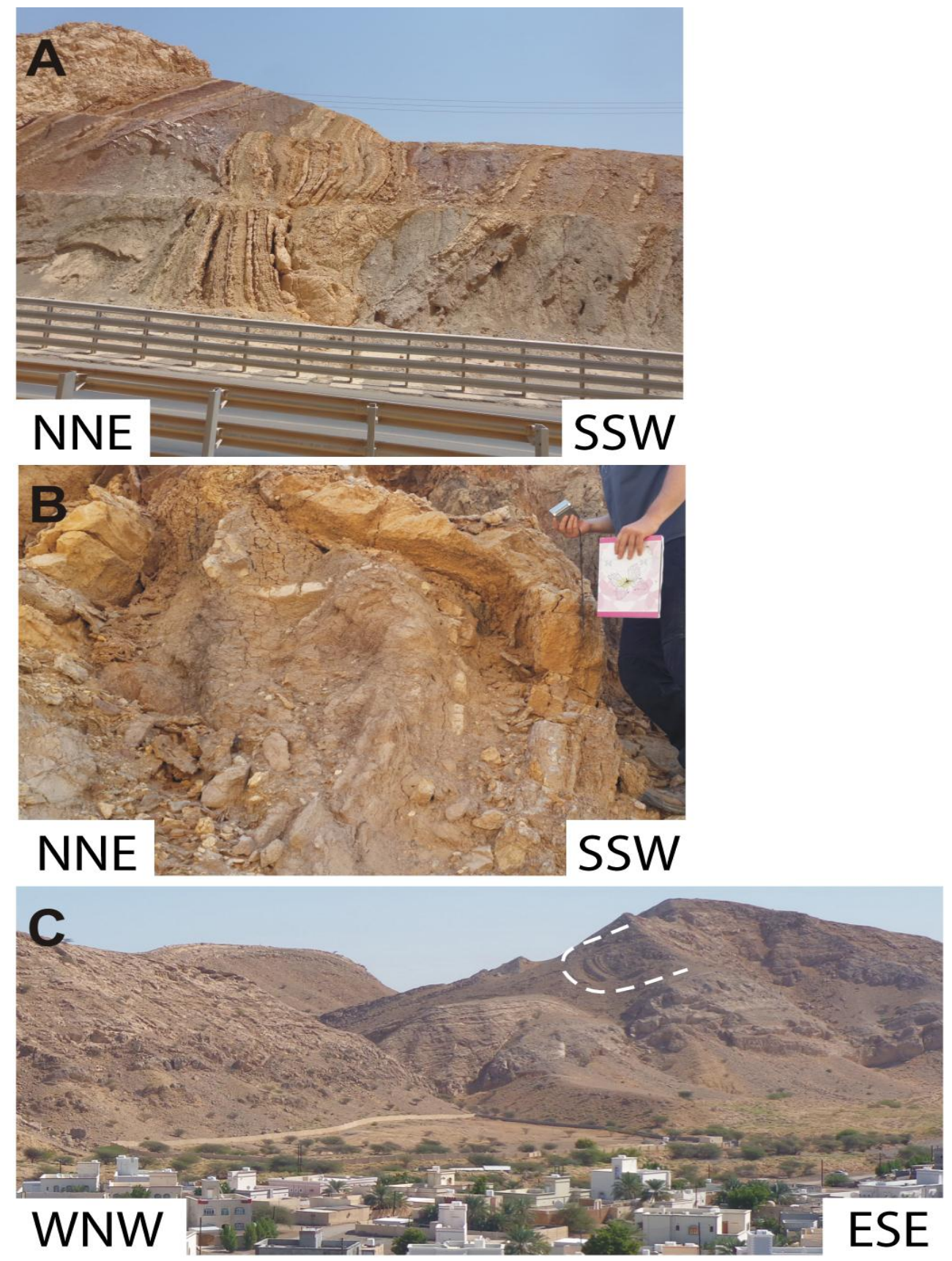

Figure 3. Folds of the Tertiary Ridge (A-C). A. Folded and faulted Rusayl Fm. Eastern side of the Al-Khod road cut, north of Al-Khod Village. The guard rails are $2 \mathrm{~m}$ high. B. Small scale fold in the Rusayl Fm. Eastern side of the Al-Khod road cut, north of Al-Khod Village. C. Large scale fold in the Jafnayn Fm. (dashed line). Natural outcrop in the Tertiary Ridge. Note the Ridge character. Houses in the foreground belong to Al-Khod Village.

Paleocene to Eocene deformation is largely extensional [5]. However, this extension is followed by some compressional deformation, still during the Eocene. Extension is attributed to Paleogene gravity collapse of the Oman Mountains [5, 6], possibly dating as post-middle Eocene [6]. A different cause was identified by [7]. They suggested that Paleogene/Neogene to Quaternary extensional faulting along WNWstriking faults was due to the flexural bulging of the under-riding Arabian Plate within the Arabia-Eurasia Collision Zone. Some workers have distinguished a late Cretaceous to early Eocene phase of extension, oriented ENE-WSW as well as two Oligocene intervals of extension, oriented NNE-SSW and NNW-SSE [8].

Whereas many studies have concentrated on the regional extensional deformation (e.g., [7, 9, 10 and sources therein]), very little has been published on post-Cretaceous compressional structures, the work by [8] being a notable exception. They determined a late Oligocene/early Miocene to Pliocene compressional phase with two episodes of different stress directions: E-W to NE-SW (early Miocene) and N-S to NNE-SSW (Pliocene). It must also be mentioned that compressional deformation may be concentrated along pre-existing 


\section{DEFORMATION OF THE TERTIARY RIDGE}

faults [5]. Compressional deformation was initiated in northern Oman coevally with the onset of the ArabiaEurasia Collision Zone in the Zagros Mountains [8].

With regard to regional strike-slip tectonics, [8] noticed that conjugate strike-slip faults are associated with the compressional stage, and that sigma 1 was oriented E-W to NE-SW. They observed three sites with conjugate sets of strike-slip faults in the Jafnayn Fm. in the Muscat area with right-lateral faults striking NESW and left-lateral faults, striking E-W. Near Al-Khod Village they found strike-slip and reverse faults, revealing a NE-SW orientation of sigma 1.

It is also worth noting that the WNW-striking Hatta Zone, at the western end of the Batinah Coast, has a left-lateral Paleogene to Neogene history [10]. Paleogene to Neogene sinistral shearing was also determined for the NW-striking Maradi Fault [7]. In both cases, the sinistral shear sense can be explained by the orientation of (rotating) sigma 1, as detected by [8].

Our study is the first detailed structural analysis of a $\sim 2 \mathrm{~km}$ wide segment of the Tertiary Ridge near Al-Khod Village. We determine the origin of conspicuous folds within parts of the Tertiary Ridge, the orientation of sigma 1 during convergence, and decipher the structural evolution of the Tertiary Ridge. Moreover, we compare our results with information on other structures, and we deduce the mechanical relationship of the ridge's structures to plate-scale tectonic processes

After a brief description of the tectonic framework and the lithological units, we present a tectonic map of the Tertiary Ridge, revealing the orientation and kinematics of the observed structural features (strike-slip, reverse and normal faults, Riedel shears, slicken lines and folds), and corresponding cross sections. Following this descriptive section, we offer a genetic interpretation of the observed structures in terms of stress orientation, time of deformation and related plate tectonic processes. Finally, we compare our results with published data. We believe our results will contribute to the understanding of the geodynamic evolution of the Oman Mountains after the ophiolite obduction during late Cretaceous times.

\section{Geological Background}

\subsection{Regional tectonic framework}

Northern Oman was the site of large scale tectonic ophiolite emplacement during the Upper Cretaceous [11]. The ophiolite is derived from a part of the Tethys Ocean, which was located to the northeast of Oman. All margins of the Arabian Plate are characterized by tectonic activities (Figure 4).

In the north, the plate is taking part in the Arabia-Eurasia collision, forming the Zagros and Makran fold and thrust belts. The onset of the deformation of the Zagros Mountain Belt dates with $22 \mathrm{Ma}$ and the convergence since that time amounts to $440 \mathrm{~km}[12]$.

To the southwest and south, the Arabian Plate terminates at the active spreading axes of the Red Sea and the Gulf of Aden, respectively. The age of the southern Red Sea is 30 to $24 \mathrm{Ma}$ and the amount of extension measures about $300 \mathrm{~km}$ [13, 14 their Figure 3]. Although the age of the Gulf of Aden is younger (20 Ma) the amount of extension is $100 \mathrm{~km}$ larger $[8,15]$.

Towards the east and the west, the Arabian Plate is limited by the dextral Owen Transform Fault and the sinistral Dead Sea Transform Zone, respectively. The Owen Transform Fault has an age of 8 Ma and a rate of dextral lateral motion of $2 \mathrm{~mm} / \mathrm{a}$ [16]. The Dead Sea Transform Fault has an age of 14 Ma [17, 18] with 100-105 km of displacement motion [19].

\subsection{Age and type of post-obduction deformation}

The Oman Mountains show clear sings of uplift. Uplift may have begun during late stages of ophiolite obduction onto the Arabian Plate during the late Cretaceous, and may have been localized and facilitated by pre-existing basement structures [7, 24]. Uplift of the domes of the Oman Mountains ensued along basement ramps [25].

Following the late Cretaceous ophiolite obduction, the Arabian Plate was also affected by continental rifting started during the early Oligocene to early Miocene in the southwest and south with a rapid stage during the early Miocene [13] (Figure 4). Rifting proceeded into the nearly synchronous opening of the NNW-SSE-striking southern part of the Red Sea and the ENE-WSW-striking Gulf of Aden [13]. This may have resulted in the formation of SE-NW-directed extensional structures in the Arabian Plate, including the Oman Mountains. On the other hand, the extensional structures may be related to flexural bulging [7] and gravitational collapse structures [9]. The latter could possibly explain a tectonic transport of the postobductional sedimentary cover toward the NE, towards the Gulf of Oman. 


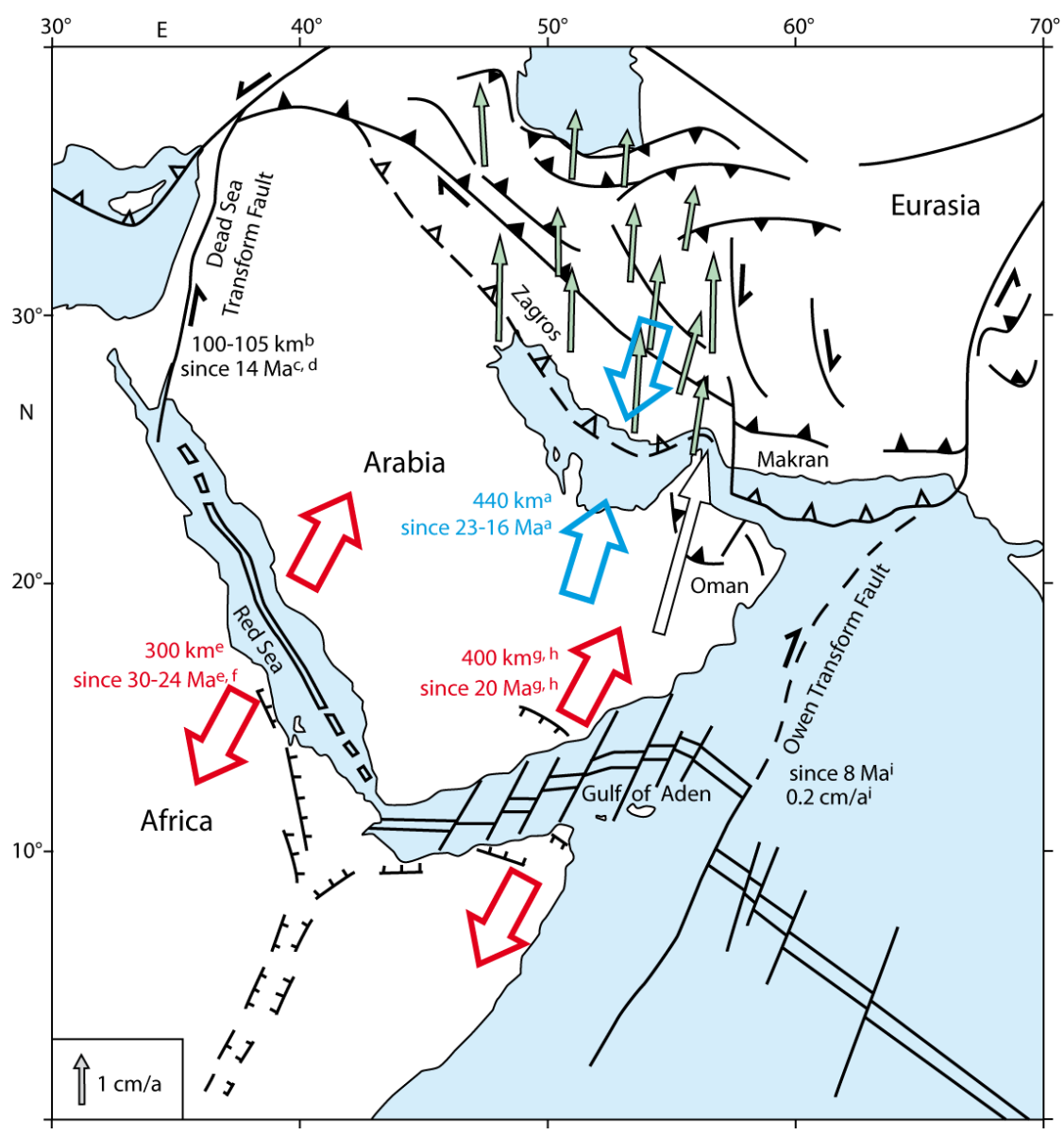

Figure 4: Tectonic setting of the Arabian Plate. Red and blue coloured symbols indicate divergence and convergence with overall amount and age, respectively. Green arrows show present-day GPS values with respect to fixed Europa from Iran [20] and white arrow from Oman [21]. a - [22]; b - [19]; c - [17]; - [18]; $\mathrm{e}-[13] ; \mathrm{f}-[14] ; \mathrm{g}-[8] ; \mathrm{h}-[15] ; \mathrm{i}-[16]$. Map modified from [23].

Immediately after, or in part overlapping with, the extensional tectonics, the Arabian Plate underwent $\sim$ NE-SW directed compression in the course of plate convergence with Eurasia forming the Zagros Fold-andThrust Belt. This started during the early Miocene (23-16 Ma [22, 26-32]) and is an ongoing process as shown, for example, by present-day convergence rates, determined by GPS measurements, between Arabia and Eurasia with $36.5 \mathrm{~mm} / \mathrm{a}$ near the Strait of Hormuz [20] (Figure 4), contributing to the Cenozoic and recent uplift of the Oman Mountains.

\subsection{Lithology}

The post-obductional sediments of the study area can be divided into the $800 \mathrm{~m}$ thick late Campanian to early Maastrichtian Al-Khod Fm. and three younger formations which collectively comprise the Tertiary Ridge [1] (Figure 5). These three formations are the Jafnayn, Rusayl and Seeb fms. The thicknesses of these formations are $126 \mathrm{~m}, 144 \mathrm{~m}$ and $600 \mathrm{~m}$, and their ages are of late Paleocene to Eocene, early Eocene, and middle to late Eocene, respectively [1-3]. The contacts between the three formations within the Tertiary Ridge are conformable, whereas the contact between the Al-Khod Fm. with the overlaying Jafnayn Fm. is marked by a fault at the southern margin of the ridge [1]. The Al-Khod Fm. consists mainly of interbedded conglomerate, lithic sandstone and shale [1]. The Jafnayn and Seeb fms. chiefly consist of nodular or nonnodular limestone and marly wackestone, whereas the Rusayl Fm. consists of shale and marl in which a central limestone unit is embedded [1].

\section{Methods}

The structures observed in the field were mapped and measured with modern fabric compasses after [33]. Because of the conspicuous folds and the obvious straight character of the Tertiary Ridge, we considered as possible genetic causes conventional compression and/or transpression and used the Harding Strain Ellipse as a tool for the tectonic interpretation [34]. In addition, we used shear sense criteria for the kinematic analysis of slickensides (see Appendix [36, his fig. 4.17]). Satellite imagery helped to identify 


\section{DEFORMATION OF THE TERTIARY RIDGE}

segments of different strike of the Tertiary Ridge. We will refer to the extensional structures as "D1" and to younger compressional structures as "D2". The measurements of the individual structures and their locations are shown in the Appendix.

\section{Structural Results}

\subsection{Left-lateral strike-slip deformation}

The Tertiary Ridge near Al-Khod Village consists of three structural domains (domains A, B and C; Figure 5). Domain A is located west of the road cut, whereas Domain B represents the main part of the study area. Domain B starts east of the road extending for $\sim 1 \mathrm{~km}$. East of Domain B starts Domain C. The two mapped and proposed main faults of Domains $\mathrm{A}$ and $\mathrm{C}$ have the same orientation (strike: $\sim 122^{\circ}$ to $302^{\circ}$ ), whereas the two mapped main strike-slip faults in Domain B are slightly oblique $\left(\sim 10^{\circ}\right)$ to the main faults in the two domains (strike: $\sim 112^{\circ}$ to $292^{\circ}$ ). Domain C is inaccessible for field work.

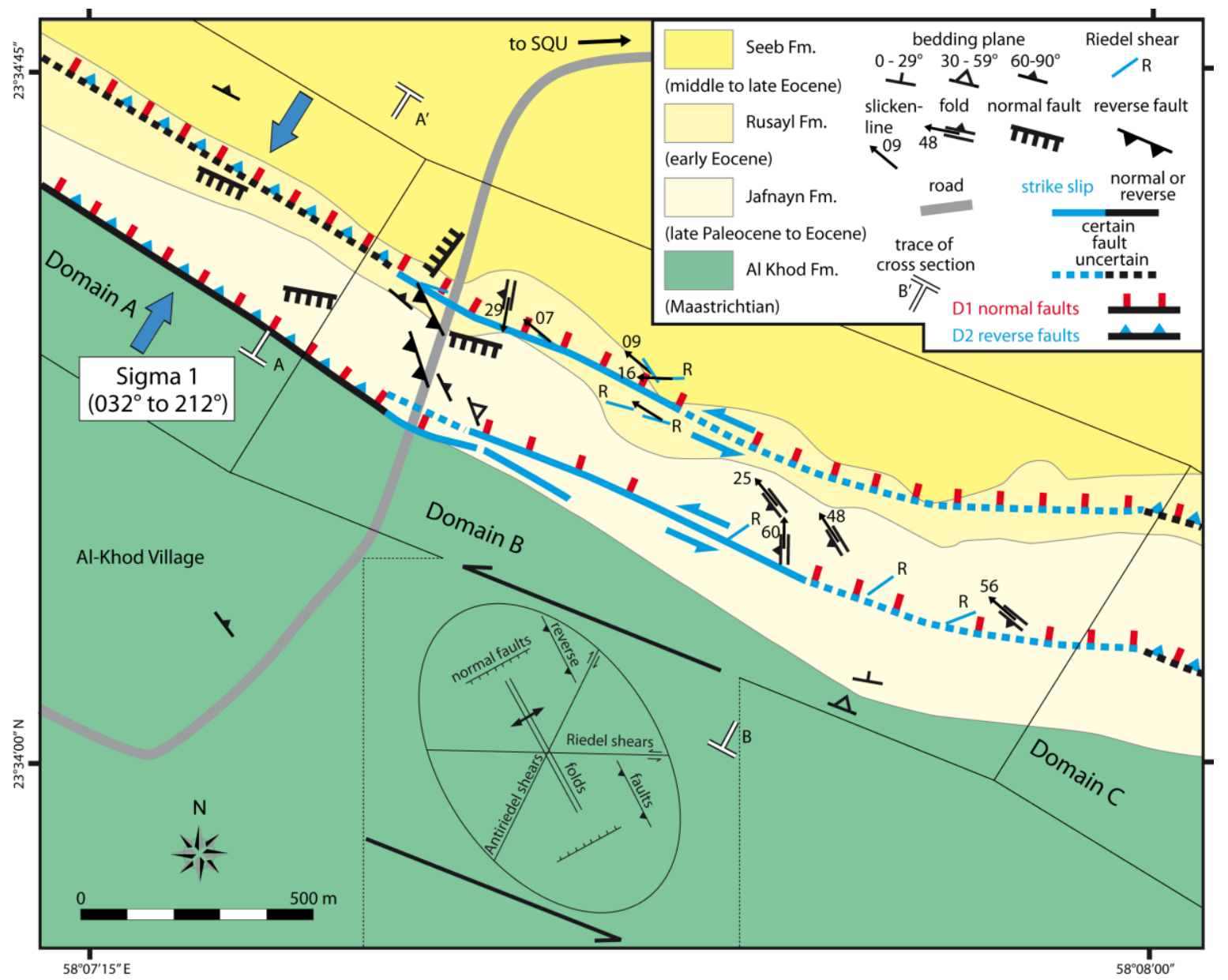

Figure 5. Tectonic map of the Tertiary Ridge at the Al-Khod Village. Based on the analysed structures, sigma 1 is oriented perpendicular to the strike of the Tertiary Ridge of domains A and C. Note that the D1 extensional structures are reactivated as D2 compressional structures. Inset at the lower part shows leftlateral Harding Strain Ellipse [34] for a theoretical pattern of structures between two strike-slip faults.

A NW striking strike-slip fault could only be observed in Domain B. Its shear sense is sinistral (Figures $5 \& 6)$ as indicated by the geometric relationships between the fault and associated structures, including Riedel shears, folds, reverse and normal faults. We observed numerous horizontal and gently dipping slickenlines, indicating that strike-slip was significant in the Tertiary Ridge. However, our slickenside analyses sensu [35] also revealed a strike-slip that was opposite to the sinistral motion. There are also slickensides, showing dip-slip or oblique slip, sometimes in one and the same outcrop.

The strike-slip motion probably occurred not only along a single fault but rather within a shear zone, composed of two sub-parallel faults (Figures $5 \& 6$ ). The first of these is largely located at the boundary between the Al-Khod and the Jafnayn fms (Domain A). Within Domain B this fault shifts into the Jafnayn Fm. (Figure 5). The second fault is assumed to be located to the north within the Rusayl Fm. (Figure 5). 

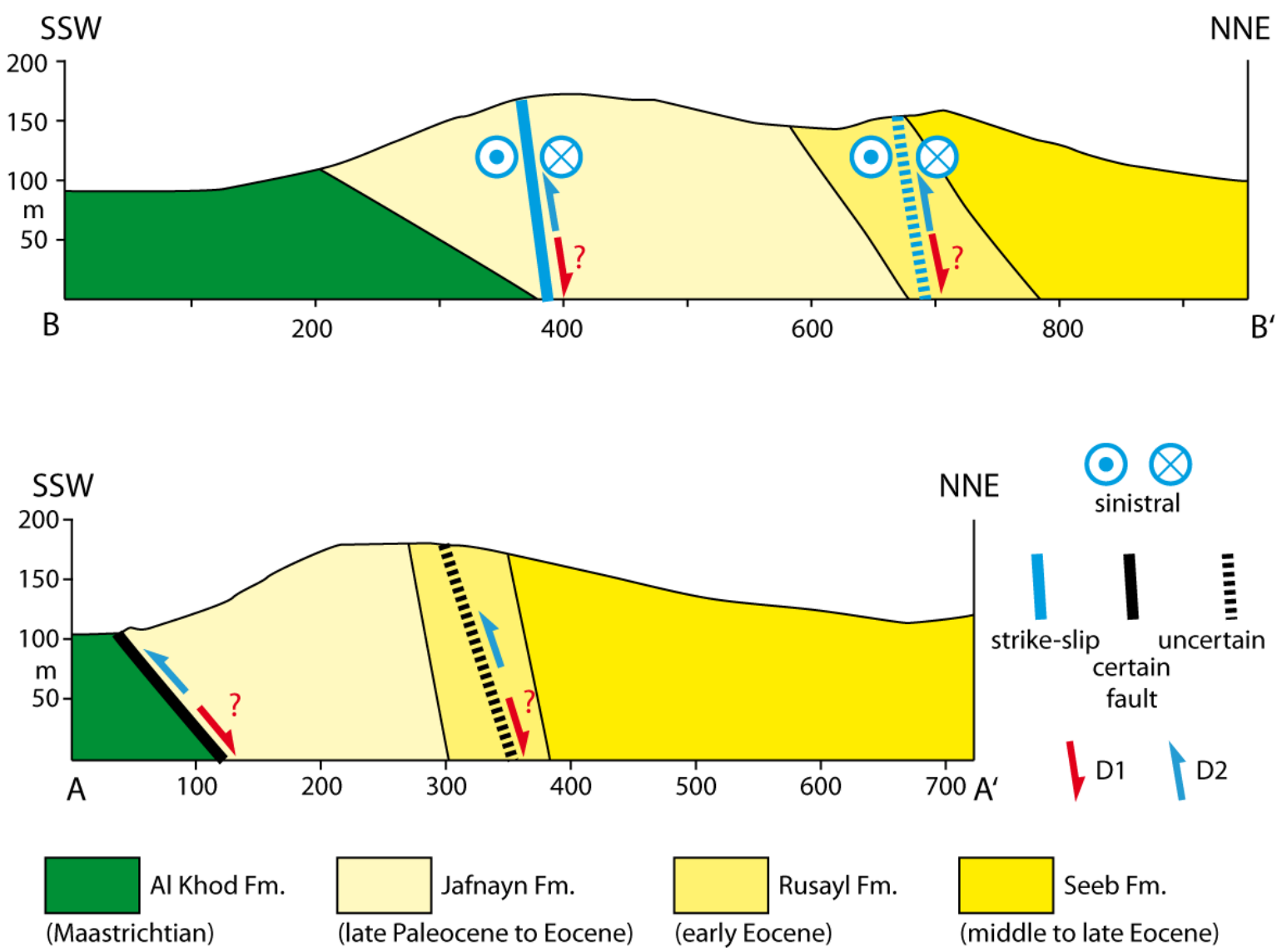

Figure 6. Cross section perpendicular to the strike of the Tertiary Ridge. See Figure 5 for a trace of the cross sections. A-A' is located in Domain A and B-B' is located in Domain B. Note that the D1 extensional structures are reactivated as D2 compressional structures. In Domain A the southern fault is found at the contact between the Al-Khod and the Jafnayn fms. Towards the east, in Domain B, the fault is shifting into the Jafnayn Fm.

We point out that the incompetent, marly Rusayl Fm. is highly deformed over its entire thickness. Deformation in the Rusayl Fm. is stronger than in the Jafnayn Fm. and much stronger than in the Seeb Fm. Evidently, strain is most concentrated in the Rusayl Fm. At and near the road cut in Domain B five clear evidence for a left-lateral strike-slip fault within the Rusayl Fm. exists: (1) Deformation within the Rusayl Fm. is most intense near the contact to the Seeb Fm. (Figures 3 \& 5); (2) Several fault planes with Riedel shears and slickenlines are found within the Rusayl Fm. and at the lowermost part of the Seeb Fm. (stops 28 - 31, Appendix). Although the mineral steps along the fault plains do not show a conclusive indication for the sense of shear, the overall orientation of the Riedel shears with respect to the mapped main strike-slip fault points to sinistral motion; (3) There is a text-book example of a coarse tectonic breccia along a vertical Riedel shear plane or "Riedel fault" within the Rusayl Fm. (Figure 7a, stop 29, Appendix); (4) This breccia is found on a large $(\leq 100 \mathrm{~m}$ long) asymmetric limestone boudin within the central part of the Rusayl Fm. The displacement of $50 \mathrm{~m}$ between two asymmetric boudins is sinistral (Figure 7b, stops 31 \& 32, Appendix); (5) There is steepening of the bedding plane of the Rusayl Fm. and the lowermost part of the Seeb Fm. in proximity of the contact between the two formations (Figure 7c). This steepening indicates the presence of an overall subvertical fault within the Rusayl Fm. Because of its steep character this sub vertical fault is considered as a strike-slip fault.

This makes it very likely that a major strike-slip fault is located within this formation. The majority of the structures of Domain B are concentrated within the Jafnayn and the Rusayl fms. Only a few structures are found in the lowermost part of the Seeb Fm. The overall compression is assumed to be perpendicularly oriented to the Tertiary Ridge in domains $\mathrm{A}$ and $\mathrm{C}$ and, hence, NNE-SSW directed $\left(032^{\circ}\right.$ to $212^{\circ} \pm 2^{\circ}$; Figure 5). 

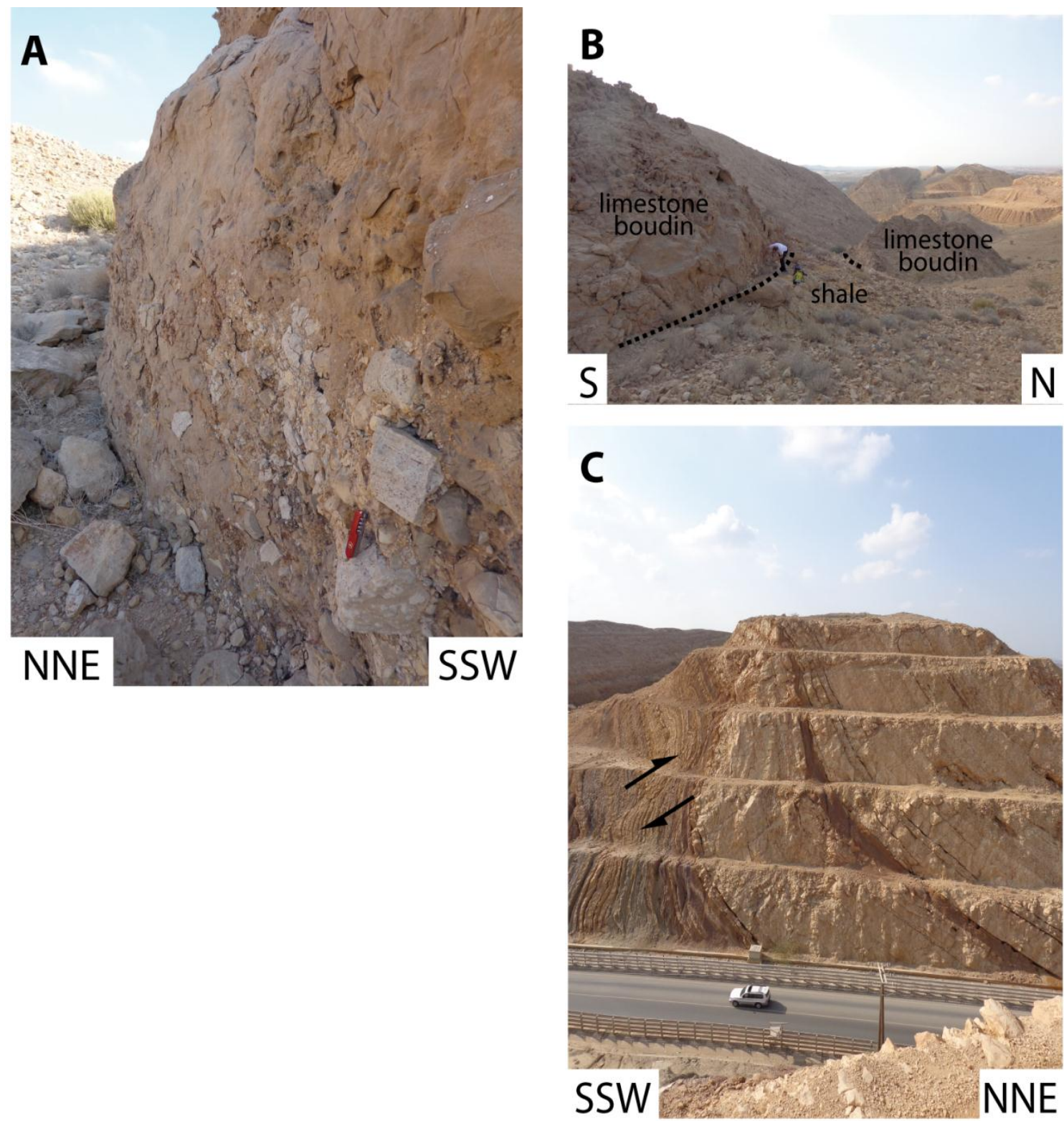

Figure 7. Tectonic structures along the Tertiary Ridge in Domain B.

A. Coarse tectonic breccia on a vertical Riedel shear (stop 29, Appendix).

B. Asymmetric limestone boudins in the central part of the Rusayl Fm. Note the vertical fault plane on the boudin with the tectonic breccia of Figure 7a is investigated by the first author. The dashed lines mark the contact of the shale with the two limestone boudins (left limestone - stop 29; right limestone - stop 31).

C. Steepening of the bedding plane of the dark Rusayl and the lowermost part of the lighter Seeb Fms. Note a reverse fault with a top to the NNE displacement within the shale of the Rusayl Fm. and a subvertical fault at the contact between Rusayl Fm. and Seeb Fm. (stop 33, Appendix).

\subsection{Structural elements}

The measurements of the individual structures and their locations are shown in the Appendix. The size of the NE to SW striking Riedel shear faults measures several square meters. The orientation of these ENE to WSW striking sub-vertical faults is oblique $\left(\sim 30-40^{\circ}\right)$ to the main strike-slip fault (Figure 5). Their obliquity indicates that they are Riedel shears of the strike-slip fault. No sense of shear indicators (e.g., mineral steps) along the Riedel faults could be found. Normal faults are observed along the road cut at the transition between domains A and B. Some of these normal faults have an oblique displacement (e.g., stop 16). These 
faults range from several square centimeters to some square meters in size with a dip-slip displacement of several centimeters to a maximum of two meters.

Folds at the scale of several meters to 100 meters were measured. The larger folds are visible along the folded lower and upper contacts of the Rusayl Fm. (Figure 5). The orientation of all these folds is similar, displaying steep to subvertical fold axial planes, striking NNW to SSE and dipping steeply to the WSW, and fold axes plunging gently to moderately towards the NW. Exceptions are one fold with a fold axis, plunging to the south (stop 17, Figure $3 \mathrm{~b}$ ) and another fold with a fold axis plane, striking to the NNE (stop 8 , Figure 3c). The shape of the folds is mostly tight. One syncline, however, is open (stop 14, Appendix and Figure A1).

According to Figure 5, the general direction of dip in the three formations is NNE. At the easternmost part of the study area (transition between domains B \& C, stops 8 \& 9) the Al-Khod Fm. dips more steeply than the overlying Jafnayn Fm., which indicates a low-angle discontinuity between both formations.

Many faults are steeply-dipping and strike NW; those found west of the road cut especially are possibly D1 normal or D2 reverse faults, since they display sub-vertical slickenlines. One of the faults shows a completely different orientation (strike to the NE) with dip-slip slickenlines. The measurements of the individual structures and their locations are shown in the Appendix.

\section{Synthesis of Faulting and Geodynamic Interpretation}

On the basis of field observations along the study area, two main phases of deformation have been recognized. We describe them in order of age, from older to younger.

\subsection{NE-SW directed extensional phase}

A set of SE-NW striking normal faults, belonging to D1 within both the Jafnayn and Rusayl fms. indicates NE directed extension (stops 9 \& 10). Similar striking extensional structures were identified along the northern and southern margins of the Gulf of Aden in Oman [36, 37], in Yemen [38], Socotra Island [39] and in the Oman Mountains, including the Tertiary Ridge [9]. These extensional structures are associated with Oligocene rifting of the Gulf of Aden [8] or are gravity-driven, facilitating tectonic transport away from the Oman Mountains and towards the Gulf of Oman [9].

Since the Tertiary Ridge strikes $\sim 122^{\circ}-302^{\circ}$, at a high angle but not perpendicular to the proposed NE direction of extension, extension with a horizontal component (oblique extension,) along the D1 normal faults cannot be excluded. If a strike-slip component was involved during the D1 extensional phase, this horizontal component must have been dextral.

\subsection{NE-SW directed compressional phase}

Figure 8. provides a schematic model for the D2 compressional phase, which is marked by a left-lateral strike-slip fault, traced within the Jafnayn Fm. and a proposed second left-lateral strike-slip fault within the Rusayl Fm. (Figure 5). The D2 shear sense within Domain B is interpreted as sinistral, based on analysis of the geometric relationships between the small-scale structures (Riedel shears, folds and reverse faults) with that of the main fault(s), and a comparison of these relationships with those shown on the Harding Strain Ellipse [34]; Figure 5). Field observations and measurements reveal that the compressional structures (folds $\&$ reverse faults) are oriented around $45^{\circ}$ with respect to the main strike-slip fault. Riedel shears are oriented at relatively low to moderate angle to the main strike-slip fault. These observations match with the sinistral Harding Strain Ellipse (Figure 5). The fact that compressional structures are more prevalent than extensional ones leads us to interpret transpressional conditions for Domain B.

The model of Figure 8 shows the mechanisms of D2 transpressional left-lateral strike-slip faulting which was controlled by the orientation of the tectonic structures relative to the direction of D2 compressional stress (sigma 1 ). The direction of sigma 1 is slightly oblique $\left(\sim 10^{\circ}\right)$ to the main strike-slip faults in Domain B which induces oblique, left-lateral motion (Figure 5), while to the east and west of Domain $\mathrm{B}$, the tectonic units are perpendicularly oriented to sigma 1, resulting in reactivation of the extensional structures as reverse faults without horizontal movement (Figure 5). This model suggests that the pre-existing D1 normal faults formed during the NE oriented extensional phase were reactivated as D2 reverse faults during this NE compressional phase (domains A \& C; Figure 5). 


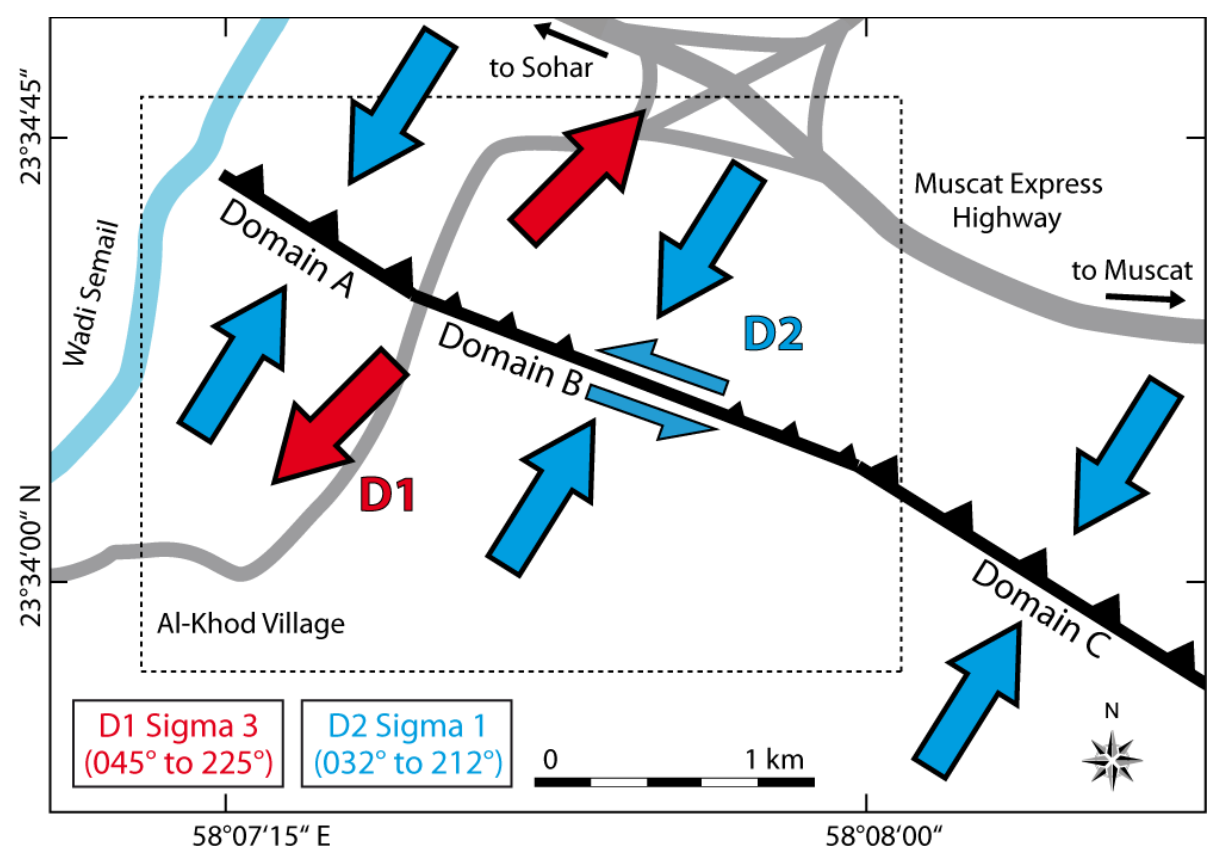

Figure 8. Schematic model for the post-obductional stress development and type of faulting along the Tertiary Ridge at the Al-Khod Village. NE-SW directed red arrows indicate the D1 extensional direction during the Oligocene. Blue arrows indicate the D2 direction of greatest stress during Miocene compression (this study). The direction of D2 is perpendicular to the Tertiary Ridge in the domains A and C. Dotted box indicates the study area (Figure 5).

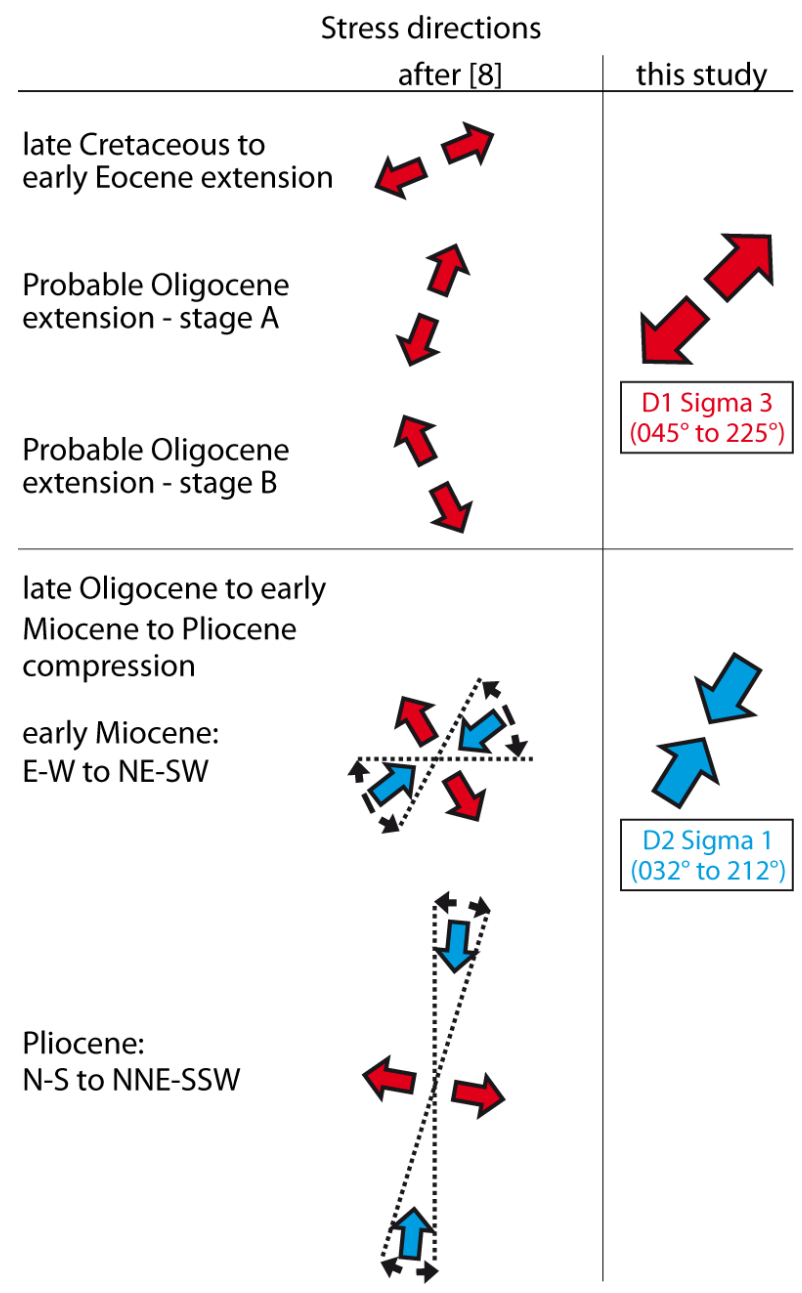

Figure 9. Juxtaposition of late Cretaceous to Pliocene stress direction in the post-obductional sediments in the vicinity of Muscat obtained from [8] and from this study (see exact locations in Figure 6 of [8]). 
Figure 9 provides a comparison of the late Cretaceous to Pliocene stress directions in the post-obductional sediments in the vicinity of Muscat obtained from [8] and from this study (see exact locations in Figure 6 of [8]). The estimated NE-SW direction of D1 extension (sigma 3) in our study coincides with the 'probable Oligocene extension stage A' of [8]. The different directions of extension in Figure 9 point to both orogenic collapse plus regional extension due to rifting as mentioned in section 5.1. The final development of the leftlateral transpressive belt in Domain B in our study area is most likely a result of compression during the early Miocene. A Pliocene age can be excluded because the stress direction (sigma 1) during that time was more $\mathrm{N}-\mathrm{S}$ directed, which is slightly oblique to our measurements of $032^{\circ}$ to $212^{\circ}$ (Figures $8 \& 9$ ).

\section{Conclusion}

The present work integrates field mapping and satellite image analysis to reveal the mechanisms, fault kinematics, and relative age of faulting within the Tertiary Ridge in the vicinity of Al-Khod Village. The Tertiary Ridge was affected by the D1 extensional event, which may be related to the opening of the Red Sea and the Gulf of Aden in Oligocene times. D1 normal faults where reactivated during the D2 compressional event during the Miocene.

A strike-slip fault system occurs in two sub-parallel WNW-ESE striking branches of a left-lateral strike-slip fault zone that have accommodated transpressional stress in between them (Figure 5). This system formed owing to $\sim$ NNE-SSW D2 compressional forces, perpendicular to the overall trend of the Tertiary Ridge in the study area.

A new model explains the mechanisms of D2 strike-slip faulting (Figure 7). The driving forces for the post-Oligocene compressional deformation of the post-obduction succession in the vicinity of Al-Khod Village are related to the contemporaneous collision between the Arabian and the Eurasian plates, resulting in the formation of the Zagros Fold-and-Thrust Belt. Because Domain B of the Tertiary Ridge is slightly oblique $\left(\sim 10^{\circ}\right)$ to the direction of D2 collision/compression, transpressional deformation ensued.

If the direction of sigma 1 was the same along the entire Tertiary Ridge as in the vicinity of Al-Khod Village, then similar structures must exist in the remaining part of the ridge. Compressional structures should be found in parts of the Tertiary Ridge that are oriented WNW-ESE, similarly to in domains A and C. In differently oriented parts, transpressional structures should be present. These structures should either be of sinistral or dextral shear origin, depending on the polarity of their obliquity with respect to the orientation to sigma 1.

\section{Acknowledgment}

This article is the overall result of a Final Year Project of Sawsan S. Al-Sadi, submitted in May 2015 to the College of Science at Sultan Qaboos University (SQU). We are indebted to Mohammed Al Wardi (SQU) for helpful discussions, the translation of the Abstract and the title into Arabic, and as a reviewer. Finally, we thank two anonymous reviewers and Dr. Iftikhar Ahmed (SQU) for critical and constructive comments.

\section{References}

1. Nolan, S.C., Skelton, P.W., Clissold, B.P. and Smewing, J.D. Maastrichtian to Early Tertiary stratigraphy and paleogeography of the Central and Northern Oman Mountains. In The Geology and Tectonics of the Oman Region, (Eds. Robertson, A.H.F., Ries, M.P. and Ries, A.C.), Geological Society, London, Special Publications, 1990, 49, 495-519.

2. Dill, H.G., Wehner, H., Kus, J., Botz, R., Berner, Z., Stüben, D. and Al-Sayigh, A. The Eocene Rusayl Formation, Oman, carbonaceous rocks in calcareous shelf sediments. Environment of deposition, alteration and hydrocarbon potential. International Journal of Coal Geology, 2007, 89-123.

3. Hersi, O.S. and Al Harthi, A. Lithofacies attributes of a Transgressive Carbonate System: The Middle Eocene Seeb Formation, Al Khoudh area, Muscat, Oman. SQU Journal for Science, 2010, 15, 41-54.

4. Villey, M., de Gramont, X. and Le Métour, J. Geological map of Seeb, sheet NF40-3C, scale 1:100.000, 1986, Directorate General of Minerals, Oman Ministry of Petroleum and Minerals.

5. Hanna, S. The Alpine deformation of the Central Oman Mountains. In The Geology and Tectonics of the Oman Region, (Eds. Robertson, A.H.F., Ries, M.P. and Ries, A.C.), Geological Society, London, Special Publications, 1990, 49, 341-359.

6. Coffield, D.Q. Structures associated with nappe emplacement and culmination collapse in the Central Oman Mountains. In The Geology and Tectonics of the Oman Region, (Eds. Robertson, A.H.F., Ries, M.P. and Ries, A.C.), Geological Society, London, Special Publications, 1990, 49, 447-458.

7. Kusky, T., Robinson, C. and El-Baz, F. Tertiary-Quaternary faulting and uplift in the northern Oman Mountain. Journal of the Geological Society, London, 2005, 162, 871-888. 


\section{DEFORMATION OF THE TERTIARY RIDGE}

8. Fournier, M., Lepvrier, C., Razin, P. and Jolivet, L. Late Cretaceous to Paleogene Post-obduction extension and subsequent Neogene compression in Oman Mountains. GeoArabia, 2006, 4, 17-40.

9. Mann, A., Hanna, S.S. and Nolan, S.C. The post-Campanian tectonic evolution of the Central Oman Mountains: Tertiary extension of the Eastern Arabian Margin. In The Geology and Tectonics of the Oman Region, (Eds. Robertson, A.H.F., Ries, M.P. and Ries, A.C.), Geological Society, London, Special Publications, 1990, 49, 549-563.

10. Roberston, A.H.F., Kemp, A.E.S., Rex, D.C. and Blome, D. Sedimentary and structural evolution of a continental margin transform lineament: the Hatta Zone, Northern Oman Mountains. In The Geology and Tectonics of the Oman Region, (Eds. Robertson, A.H.F., Ries, M.P. and Ries, A.C.), Geological Society, London, Special Publications, 1990, 49, 285-305.

11. Glennie, K.W., Boeuf, M.G.A., Hughes Clarke, M.W., Moody-Stuart, M., Pilaar, W.F.H. and Reinhardt, B.M. Late Cretaceous nappes in Oman Mountains and their geologic evolution. American Association of Petroleum Geologists Bulletin, 1973, 57, 5-27.

12. Mouthereau, F. Timing of uplift in the Zagros belt/Iranian plateau and accommodation of late Cenozoic Arabia-Eurasia convergence. Geological Magazine, 2011, 148(5-6), 726-738, doi: 10.1017/S0016756811000306.

13. Bosworth, W., Huchon, P. and McClay, K. The Red Sea and Gulf of Aden Basins. Journal of African Earth Sciences, 2005, 43, 334-378, doi: 10.1016/j.jafrearsci.2005.07.020.

14. Reilinger, R. and McClusky, S. Nubia-Arabia-Eurasia plate motions and the dynamics of Mediterranean and Middle East tectonics. Geophysical Journal International, 2011, 186, 971-979, doi: 10.1111/j.1365246X.2011.05133.x.

15. Fournier, M., Chamot-Rooke, N., Petit, C., Huchon, P., Al-Kathiri, A., Audin, L., Beslier, M.O., d'Acremont, E., Fabbri, O., Fleury, J.-M., Khanbari, K., Lepvrier, C., Leroy. S., Maillot, B. and Merkouriev, S. Arabia - Somalia plate kinematics, evolution of the Aden - Owen - Carlsberg triple junction, and opening of the Gulf of Aden. Journal of Geophysical Research, 2010, 115, B04102, doi: 10.1029/2008JB006257.

16. Fournier, M., Chamot-Rooke, N., Petit, C., Fabbri, O., Huchon, P., Maillot, B. and Lepvrier, C. In situ evidence for dextral active motion at the Arabia-India plate boundary. Nature Geoscience, 2008, 1, 5458, doi: 10.1038/ngeo.2007.24.

17. Bayer, H.-J., Hötzl, H., Jado, A.R., Roscher, B. and Voggenreiter, W. Sedimentary and structural evolution of the northwest Arabian Sea Margin. Tectonophysics, 1988, 153, 137-152.

18. Makris, J. and Rihm, R. Shear controlled evolution of the Red Sea: pull apart model. Tectonophysics, 1991, 198, 441-446.

19. Walley, C.D. Some outstanding issues in the geology of Lebanon and their importance in the tectonic evolution of the Levantine region. Tectonophysics, 1998, 298, 37-62.

20. Vernant, P., Nilforoushan, F., Hatzfeld, D., Abbassi, M.R., Vigny, C. Masson, F., Nankali, H., Martinod, J., Ashtiani, A., Bayer, R., Tavakoli, F. and Chéry, J. Present-day crustal deformation and plate kinematics in the Middle East constrained by GPS measurements in Iran and northern Oman. Geophysical Journal International, 2004, 157, 381-398, doi: 10.1111/j.1365-246X.2004.02222.x.

21. McClusky, S., Balassanian, S., Barka, A., Demir, C., Ergintav, S., Georgiev, I., Gurkan, O., Hamburger, M., Hurst, K., Kahle, H., Kastens, K., Kekelidze, G., King, R., Kotzev, V., Lenk, O., Mahmoud, S., Mishin, A., Nadariya, M., Ouzounis, A., Paradissis, D., Peter, Y., Prilepin, M., Reilinger, R., Sanli, I., Seeger, H., Tealeb, A., Toksöz, M.N. and Veis, G. Global Positioning System constraints on plate kinematics and dynamics in the eastern Mediterranean and Caucasus. Journal of Geophysical Research, 2000, 105, 5695-5719.

22. McQuarrie, N. and van Hinsbergen, D.J.J. Retrodeforming the Arabia-Eurasia collision zone: Age of collision versus magnitude of continental subduction. Geology, 2013, 41(3), 315-318, doi: 10.1130/G33591.1.

23. Burg, J.-P. Internet webpage of the ETH Zürich to 'Oman ein Obduktionsorogen' http://www.files.ethz.ch/structuralgeology/JPB/files/tekto/Oman.pdf. Downloaded on the 09.06.2015.

24. Le Métour, J., Béchennec, F. and Roger, J. Late Permian birth of the Neo-Tethys and development of its southern continental margin in Oman. In Middle East Petroleum Geosciences, (Ed. Husseini, M.I.), Middle East Petroleum Geosciences, GEO’94. Gulf Petrolink. Bahrain, 1995, 2, 643-654.

25. Bernoulli, D. and Weissert, H. The upper Hawasina nappes in the central Oman Mountains: stratigraphy, palinspastic and sequence of nappe emplacement. Geodinamica Acta, 1987, 1, 47-58.

26. Agard. P., Omrani, J., Jolivet, L. and Mouthereau, F. Convergence history across Zagros (Iran): Constraints from collisional and earlier deformations. International Journal of Earth Sciences, 2005, 94, 401-419, doi: 10.1007/s00531-005-0481-4.

27. Gavillot, Y., Axen, G.J., Stockli, D.F., Horton, B.K. and Fakhari, D. Timing of thrust activity in the High Zagros fold-thrust belt, Iran, from (U-Th)/He thermochronology. Tectonics, 2010, 29, T4025, doi: $10.1029 / 2009 T C 002484$. 
28. Khadivi, S., Mouthereau, F., Barbarand, J., Adatte, T. and Lacombe, O. Constraints on paleodraingae evolution induced by uplift and exhumation on the southern flank of the Zagros-Iranian Plateau. The Geological Society of London Journal, 2012, 169, 83-97, doi: 10.1144/0016-76492011-031.

29. McQuarrie, N. Crustal scale geometry of the Zagros fold-thrust belt, Iran. Journal of Structural Geology, 2004, 26, 519-535, doi: 10.1016/j.jsg.2003.08.009.

30. Robertson, A.H.F. Mesozoic-Tertiary tectonicsedimentary evolution of a south Tethyan oceanic basin and its margins in southern Turkey. In Tectonics and Magmatism in Turkey and the Surrounding Area, (Eds. Bozkurt, J. A. Winchester, E. and Piper, J. D. A.), Geological Society Special Publication, 2000, 173, 97-138.

31. Sherkati, S., Letouzey, J. and Frizon de Lamotte, D. Central Zagros fold-thrust belt (Iran): New insights from seismic data, field observation, and sandbox modeling. Tectonics, 2006, 25, TC4007, doi: 10.1029/2004TC001766.

32. Vergés, J., Saura, E., Casciello, E., Fernàndez, M., Villaseñor, A., Jiménez-Munt, I. and GarcíaCastellanos. Crustal-scale cross-sections across the NW Zagros belt: Implications for the Arabian margin reconstruction. Geological Magazine, 2011, 148, 739-761, doi: 10.1017/S0016756811000331.

33. Clar, E. Ein zweikreisiger Geologen- und Bergmannskompaß zur Messung von Flächen und Linearen (Mit Bemerkungen $\mathrm{zu}$ den feldgeologischen Messungsarten). Verhandlungen der Geologischen Bundesanstalt Wien, 1954, 201-215.

34. Harding, T. P. Petroleum traps associated with wrench faults. American Association of Petroleum Geologists Bulletin, 1974, 58, 7, 1290-1304.

35. Angelier, J. Fault Slip Analysis and Paleostress Reconstruction. In Continental Deformation, (Ed. Hancock, P.L.), Pergamon Press, Oxford, 53-100.

36. Lepvrier, C., Fournier, M., Bérard, T. and Roger, J. Cenozoic extension in coastal Dhofar (southern Oman): Implications on the oblique rifting of the Gulf of Aden. Tectonophysics, 2002, 357, 279-293.

37. Fournier, M., Bellahsen, N., Fabbri, O. and Gunnell, Y. Oblique rifting and segmentation of the NE Gulf of Aden passive margin. Geochemistry Geophysics Geosystems, 2004, 5, Q11005, doi: 10.1029/2004GC000731.

38. Huchon, P. and Khanbari, K. Rotation of the syn-rift stress field of the northern Gulf of Aden margin, Yemen. Tectonophysics, 2003, 364, 147-166.

39. Fournier, M.P., Huchon, K., Khanbari, K. and Leroym, S. Asymmetry and segmentation of passive margin in Socotra, Eastern Gulf of Aden, controlled by detachment faults. Geochemistry, Geophysics, Geosystems, 2007, 8, Q03007, doi: 10.1029/2006GC001526.

\section{Appendix:}

The stops of the study area (Figure 5) are shown in Figure A1 and listed in Tables A1-A4.

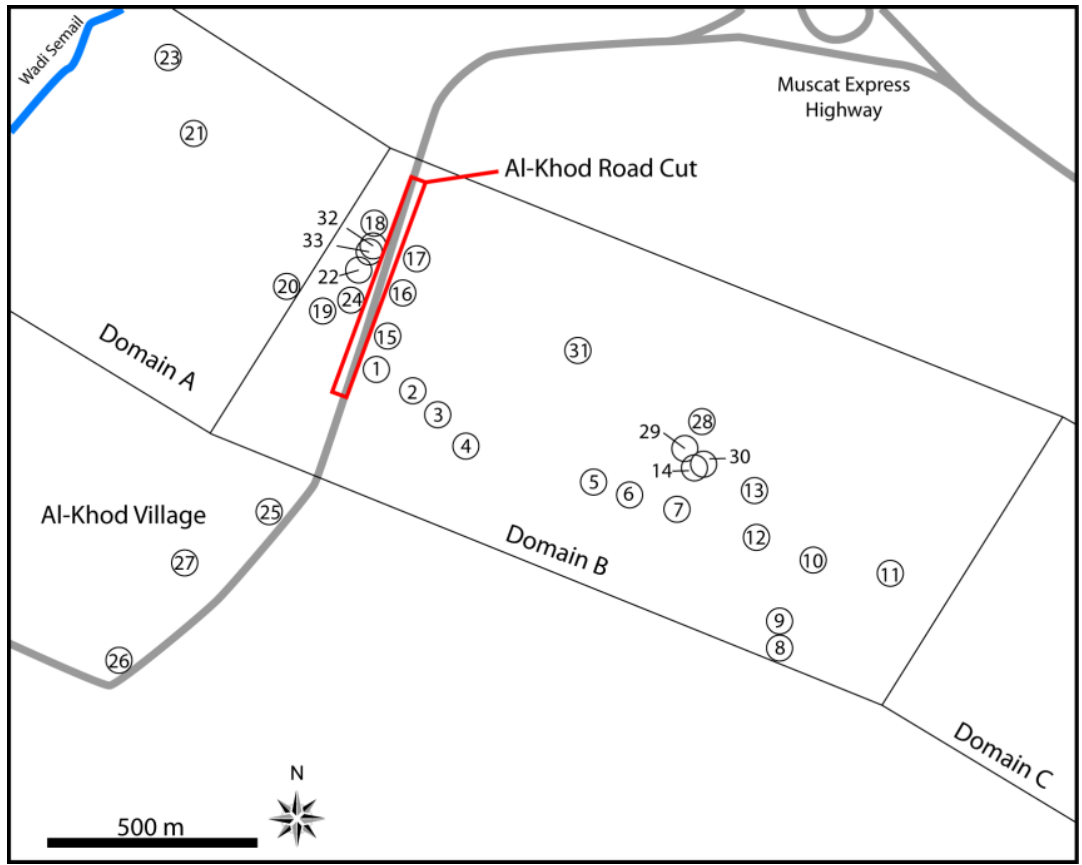

Figure A1. Location map of the study area. 


\section{DEFORMATION OF THE TERTIARY RIDGE}

Table A1. Bedding-plane measurements after [1]

\begin{tabular}{ccccc}
\hline Stop\# & $\mathrm{N}$ & $\mathrm{E}$ & Elevation $[\mathrm{m}]$ & Measurements \\
\hline 1 & $23^{\circ} 34^{\prime} 13.1^{\prime \prime}$ & $58^{\circ} 07^{\prime} 40.9^{\prime \prime}$ & 89 & $065 / 58$ \\
8 & $23^{\circ} 33^{\prime} 52.3^{\prime \prime}$ & $58^{\circ} 08^{\prime} 14 .^{\prime \prime}$ & 111 & $010 / 41$ \\
9 & $23^{\circ} 33^{\prime} 543^{\prime \prime}$ & $58^{\circ} 08^{\prime} 14.0^{\prime \prime}$ & 129 & $009 / 16$ \\
15 & $23^{\circ} 34^{\prime} 19.5^{\prime \prime}$ & $58^{\circ} 07^{\prime} 41.3^{\prime \prime}$ & 109 & $247 / 75$ \\
19 & $23^{\circ} 34^{\prime} 18.4^{\prime \prime}$ & $58^{\circ} 07^{\prime} 34.9^{\prime \prime}$ & 85 & $028 / 55$ \\
22 & $23^{\circ} 34^{\prime} 31.1^{\prime \prime}$ & $58^{\circ} 07^{\prime} 26.0^{\prime \prime}$ & 99 & $040 / 84$ \\
23 & $23^{\circ} 34^{\prime} 38.4^{\prime \prime}$ & $58^{\circ} 07^{\prime} 21.5^{\prime \prime}$ & 89 & $030 / 78$ \\
27 & $23^{\circ} 33^{\prime} 57.7^{\prime \prime}$ & $58^{\circ} 07^{\prime} 24.6^{\prime \prime}$ & 109 & $130 / 60$ \\
\hline
\end{tabular}

Table A2. Fold measurements after [1]

\begin{tabular}{cccccc}
\hline Stop\# & N & E & Elevation $[\mathrm{m}]$ & Fold axis & Fold axial plane \\
\hline 7 & $23^{\circ} 34^{\prime} 02.4^{\prime \prime}$ & $58^{\circ} 08^{\prime} 07.2^{\prime \prime}$ & 138 & $006 / 60$ & NNE-SSW/subvertical \\
13 & $23^{\circ} 34^{\prime} 04.1^{\prime \prime}$ & $58^{\circ} 08^{\prime} 12.0^{\prime \prime}$ & 152 & $336 / 48$ & SE-NW/subvertical \\
14 & $23^{\circ} 34^{\prime} 05.8^{\prime \prime}$ & $58^{\circ} 08^{\prime} 08.4^{\prime \prime}$ & 135 & $330 / 25$ & SE-NW/subvertical \\
17 & $23^{\circ} 34^{\prime} 24.4^{\prime \prime}$ & $58^{\circ} 07^{\prime} 43.1^{\prime \prime}$ & 127 & $208 / 29$ & NNE / SSW \\
\hline
\end{tabular}

Table A3. Riedel-shear measurements after [1]

\begin{tabular}{|c|c|c|c|c|}
\hline Stop\# & $\mathrm{N}$ & $\mathrm{E}$ & Elevation [m] & Measurements \\
\hline 6 & $23^{\circ} 34^{\prime} 03.6^{\prime \prime}$ & $58^{\circ} 08^{\prime} 03.8^{\prime \prime}$ & 119 & $\begin{array}{l}060 / 90 \\
070 / 90 \\
062 / 90\end{array}$ \\
\hline 10 & $23^{\circ} 24^{\prime} 00.0^{\prime \prime}$ & $58^{\circ} 08^{\prime} 20.3^{\prime \prime}$ & 150 & $\begin{array}{l}062 \text { / } 90 \\
086 \text { / } 90 \\
070 \text { / } 90 \\
060 \text { / } 90 \\
072 \text { / } 90\end{array}$ \\
\hline 12 & $23^{\circ} 34^{\prime} 00.4^{\prime \prime}$ & $58^{\circ} 08^{\prime} 13.7^{\prime \prime}$ & 173 & $235 / 43$ \\
\hline 28 & $23^{\circ} 34^{\prime} 14.5^{\prime \prime}$ & $58^{\circ} 07^{\prime} 57.2^{\prime \prime}$ & 196 & $\begin{array}{l}359 \text { / 86, with } 272 / 16 \\
\text { slicken lines }\end{array}$ \\
\hline 29 & $23^{\circ} 34^{\prime} 14.5^{\prime \prime}$ & $58^{\circ} 07^{\prime} 55.7^{\prime \prime}$ & 172 & $015 / 87$ \\
\hline 30 & $23^{\circ} 34^{\prime} 15.0^{\prime \prime}$ & $58^{\circ} 07^{\prime} 56.4^{\prime \prime}$ & 172 & $\begin{array}{c}016 \text { / } 67 \text {, with } 302 / 40 \\
\text { slicken lines }\end{array}$ \\
\hline
\end{tabular}


ANDREAS SCHARFET AL.

Table A4. Fault measurements after [1]

\begin{tabular}{|c|c|c|c|c|c|c|}
\hline Stop\# & $\mathrm{N}$ & $\mathrm{E}$ & Elevation $[\mathrm{m}]$ & Type of fault & Fault plane & Slicken lines \\
\hline 2 & $23^{\circ} 34^{\prime} 12.5^{\prime \prime}$ & $58^{\circ} 07^{\prime} 44.2^{\prime \prime}$ & 104 & Strike-slip fault & $200 / 60$ & $200 / 60$ \\
\hline 3 & $23^{\circ} 34^{\prime} 09.0^{\prime \prime}$ & $58^{\circ} 07^{\prime} 46.00^{\prime \prime}$ & 100 & Faults (undifferentiated) & $\begin{array}{l}070 / 55 \\
078 / 35 \\
011 / 77 \\
032 / 47\end{array}$ & $\begin{array}{c}140 / 31 \\
102 / 26 \\
334 / 69 \\
032 / 47\end{array}$ \\
\hline 4 & $23^{\circ} 34^{\prime} 08.5^{\prime \prime}$ & $58^{\circ} 07^{\prime} 49.7^{\prime \prime}$ & 106 & Strike-slip fault & $096 / 80$ & $160 / 10$ \\
\hline 5 & $23^{\circ} 34^{\prime} 04.3^{\prime \prime}$ & $58^{\circ} 08^{\prime} 01.4^{\prime \prime}$ & 108 & Strike-slip fault & $028 / 84$ & - \\
\hline 6 & $23^{\circ} 34^{\prime} 03.6^{\prime \prime}$ & $58^{\circ} 08^{\prime} 03.8^{\prime \prime}$ & 119 & Strike-slip fault & $120 / 90$ & - \\
\hline 10 & $23^{\circ} 34^{\prime} 00.0^{\prime \prime}$ & $58^{\circ} 08^{\prime} 20.3^{\prime \prime}$ & 150 & Strike-slip fault & $\begin{array}{l}096 / 90 \\
098 / 90 \\
102 / 90\end{array}$ & - \\
\hline 16 & $23^{\circ} 34^{\prime} 20.6^{\prime \prime}$ & $58^{\circ} 07^{\prime} 42.1^{\prime \prime}$ & 118 & Normal fault & $189 / 70$ & $268 / 33$ \\
\hline 18 & $23^{\circ} 34^{\prime} 22.7^{\prime \prime}$ & $58^{\circ} 07^{\prime} 41.8^{\prime \prime}$ & 128 & Normal fault & $296 / 69$ & $349 / 67$ \\
\hline 20 & $23^{\circ} 34^{\prime} 22.1^{\prime \prime}$ & $58^{\circ} 07^{\prime} 30.1^{\prime \prime}$ & 87 & Normal fault & $192 / 78$ & - \\
\hline 21 & $23^{\circ} 34 ' 27.4^{\prime \prime}$ & $58^{\circ} 07^{\prime} 29.2^{\prime \prime}$ & 138 & Normal fault & $208 / 81$ & - \\
\hline 28 & $23^{\circ} 34^{\prime} 14.5^{\prime \prime}$ & $58^{\circ} 07^{\prime} 57.2^{\prime \prime}$ & 196 & Strike-slip fault & $213 / 86$ & $123 / 09$ \\
\hline 31 & $23^{\circ} 34^{\prime} 17.9^{\prime \prime}$ & $58^{\circ} 07^{\prime} 51.1^{\prime \prime}$ & 126 & Strike-slip fault & $213 / 60$ & $310 / 07$ \\
\hline 32 & $23^{\circ} 34^{\prime} 22.4^{\prime \prime}$ & $58^{\circ} 07^{\prime} 42.2^{\prime \prime}$ & 173 & Strike-slip fault & $018 / 83$ & - \\
\hline 33 & $23^{\circ} 34 ' 21.7^{\prime \prime}$ & $58^{\circ} 07^{\prime} 41.8^{\prime \prime}$ & 139 & Reverse fault & $\begin{array}{l}238 / 51 \\
243 / 45\end{array}$ & - \\
\hline
\end{tabular}

\section{References}

Clar, E. Ein zweikreisiger Geologen- und Bergmannskompaß zur Messung von Flächen und Linearen (Mit Bemerkungen zu den feldgeologischen Messungsarten). Verhandlungen der Geologischen Bundesanstalt Wien, 1954, 201-215).

Received 4 October 2015

Accepted 3 January 2016 